\title{
PENALARAN KUANTITATIF SISWA SMA DALAM MENYELESAIKAN SOAL HOTS
}

\author{
Guntur Aprilaksono \\ Pendidikan Matematika STKIP PGRI Sidoarjo \\ guntur.aprilaksono@gmail.com \\ Lailatul Mubarokah \\ Pendidikan Matematika STKIP PGRI Sidoarjo \\ lailatulm11@gmail.com \\ Dewi Sukriyah \\ Pendidikan Matematika STKIP PGRI Sidoarjo \\ ryaitusukriyah@gmail.com
}

\begin{abstract}
Abstrak:
Penelitian ini bertujuan untuk mendeskripsikan penalaran kuantitatif siswa SMA dalam menyelesaikan soal HOTS. Penelitian ini dilaksanakan di kelas X MIPA 2 SMA Muhammadiyah 3 Tulangan pada semester genap tahun ajaran 2019/2020. Subjek penelitian ini adalah 3 siswa dari kelas X MIPA 2 SMA Muhammadiyah 3 Tulangan yang terdiri dari 1 siswa berkemampuan matematika tinggi, 1 siswa berkemampuan matematika sedang, dan 1 siswa berkemampuan matematika rendah. Instrumen dalam penelitian dengan pendekatan kualitatif ini menggunakan soal tes dan wawancara. Data yang diperoleh kemudian dianalisis dengan menggunakan triangulasi waktu dengan membandingkan data waktu pertama dengan waktu kedua. Hasil penelitian menunjukkan bahwa di antara ketiga siswa yang memiliki kemampuan matematika berbeda, hanya siswa berkemampuan matematika tinggi yang mampu menggunakan berbagai teknik yang dapat digunakan untuk memecahkan masalah (misalnya, menggambar gambar, menggunakan rumus, menyelesaikan persamaan).dan hanya siswa berkemampuan matematika sedang yang mampu menentukan batasan masalah
\end{abstract}

Kata Kunci: HOTS, Penalaran Kuantitatif.

\begin{abstract}
:
This study aimed to describe quantitative reasoning of high school students in solving HOTS questions. This research was conducted in SMA Muhammadiyah 3 Tulangan Academic Year 2019/2020. The subjects of this study were 3 students from Class X MIPA 2 which consisted of 1 student with high mathematical ability, 1 student with moderate mathematical ability, and 1 student with low mathematical ability. The instruments in this study which used qualitative approach were test and interview questions. The data obtained were then analyzed using time triangulation by comparing the first time data with the second time. The results showed among three students who have difference mathematical ability, there is only student that has high mathematical ability could apply various techniques to solve the problems (for the example, drew picture, used pattern, solved problem) and only student that has moderate mathematical ability could determine the limit of the problems.
\end{abstract}

Keywords: HOTS, Quantitative Reasoning. 


\section{PENDAHULUAN}

Penalaran merupakan cara berpikir spesifik untuk menarik kesimpulan dari premis-premis yang ada. Salah satu keterampilan matematika yang diperlukan dalam pembelajaran adalah kemampuan penalaran. Kemampuan penalaran sangat penting bagi siswa, karena jika siswa memiliki kemampuan dalam penalaran, maka siswa dapat menguasai matematika secara keseluruhan (Yuliardi \& Lutfi, 2018). Dari pernyataan tersebut dapat diartikan bahwa kemampuan penalaran diperlukan pada pembelajaran matematika. Menurut Kilpatrick, dkk (2001) pada pembelajaran matematika, penalaran merupakan sebuah perekat yang menggabungkan semua hal yang tujuannya menjadi pedoman untuk pembelajaran, sedangkan proses dalam penalaran melalui suatu fakta, prosedur, konsep, dan solusi lainnya. Penalaran dipandang sebagai suatu proses mencari jawaban atas permasalahan dengan cara menggabungkan fakta, prosedur, dan konsep, atau dengan metode lainnya. Carroll (1993) menyatakan bahwa secara garis besar, ada tiga kemampuan penalaran utama yaitu penalaran induktif, deduktif, dan kuantitatif. Penalaran kuantitatif adalah kemampuan yang dikembangkan untuk menganalisis informasi kuantitatif dan untuk menentukan keterampilan dan prosedur mana yang dapat diterapkan pada masalah tertentu untuk sampai pada suatu solusi Menurut NCTM (2000). Berdasarkan definisi tersebut, penalaran kuantitatif merupakan penalaran yang dikembangkan untuk menganalisis informasi kuantitatif dan menentukan keterampilan atau prosedur mana diterapkan pada suatu permasalahan. Penalaran kuantitatif merupakan penalaran yang menggunakan keterampilan matematika dasar dalam menganalisis dan menginterpretasi suatu informasi kuantiatif pada suatu permasalahan dalam kehidupan sehari-hari (Elrod, 2014). Dari pernyataan tersebut, dapat disimpulkan bahwa proses penalaran kuantitatif menggunakan kemampuan keterampilan matematika dasar dan menganalisis informasi kuantitatif untuk menyelesaikan permasalahan kontekstual. Dapat disimpulkan bahwa penalaran kuantitatif merupakan penalaran yang menggunakan kemampuan matematika untuk memperoleh informasi kuantitatif. Penalaran kuantitatif berguna langsung terhadap kehidupan sehari-hari dan menerapkan keterampilan matematika untuk menginterpretasikan data dan menyelesaikan masalah dalam konteks dunia nyata.

Pada masa ini, untuk menghadapi kemajuan jaman diperlukan skill bukan sekedar pengetahuan konseptual saja, tetapi keterampilan mengaplikasikan pengetahuan dan menerapkan keterampilan berpikir. Terkait dengan hal tersebut, Partnership for 21 st Century Skills [P21] (2002) merumuskan beberapa keterampilan yang selanjutnya disebut sebagai kecakapan abad 21 atau sering disebut $21^{\text {st }}$ Century Skills. Beberapa keterampilan yang termuat dalam kecakapan abad 21 tersebut, sering juga dikenal sebagai cakupan dari keterampilan berpikir tingkat tinggi, yaitu kreativitas, keterampilan berpikir kritis dan pemecahan masalah (Jailani, dkk 2017). Di Indonesia keterampilan berpikir tingkat 
tinggi mulai diperhatikan dengan diterapkannya Kurikulum 2013, dengan demikian keterampilan berpikir tingkat tinggi atau higher order thinking skills (HOTS) menjadi tujuan utama dalam proses pembelajaran. Berdasarkan uraian tersebut peneliti tertarik mealakukan penelitian "Penalaran Kuantitatif Siswa SMA dalam Menyelesaikan Soal HOTS”. Tujuan penelitian ini adalah mendeskripsikan penalaran kuantitatif siswa SMA dalam menyelesaikan soal HOTS. Adapun penelitian yang relevan dengan penelitian ini, yakni penelitian yang dilakukan oleh Dewi (2018) dengan judul "Profil Penalaran Kuantitatif dalam Memecahkan Masalah Matematika Ditinjau Dari Kecerdasan Numerik". Terdapat perbedaan antara penelitian Dewi (2018) dengan penelitian ini, yaitu terletak pada soal yang digunakan. Soal yang digunakan dalam penelitian ini merupakan soal berpikir tingkat tinggi (HOTS), sedangkan penelitian sebelumnya tidak menggunakan tipe soal berpikir tingkat tinggi.

HOTS dikenalkan pertama oleh Bloom, dkk (1956), seperti yang dikemukakan oleh Dafik (2014) HOTS merupakan kegiatan berpikir yang melibatkan level kognitif hirarki tinggi dari taksonomi Bloom. Buku tersebut mengkategorikan berbagai tingkat pemikiran bernama Taksonomi Bloom, mulai dari yang terendah hingga yang tertinggi. Konsep pembelajaran ini terbagi ke dalam tiga ranah, yaitu Kognitif (pengetahuan), Afektif (sikap dan perasaan), dan Psikomotorik (keterampilan). Ranah kognitif kemudian direvisi oleh Anderson, dkk. (2001), urutannya diubah menjadi: 1) mengingat (remember);2) memahami (understand); 3) mengaplikasikan (apply); 4) menganalisis (analyze); 5) menilai (evaluate); dan 6) mencipta (create). Tingkatan 1 hingga 3 sesuai konsep awalnya, dikategorikan sebagai kemampuan berpikir tingkat rendah (LOTS), sedangkan butir 4 sampai 6 dikategorikan sebagai kemampuan berpikir tingkat tinggi (HOTS).

Anderson dan Krathwohl (2001) menjelaskan bahwa analyze (menganalisis) merupakan menyusun beberapa materi menjadi bagian yang terkait untuk menyelesaikan suatu permasalahan. Jadi ranah kognitif analisis pada soal HOTS merupakan proses berpikir untuk menyelesaikan masalah dengan menentukan hubungan antar pengetahuan yang dimiliki dan menelaah kaitannya dengan konteks masalah sehingga dapat dimanfaatkan untuk menemukan cara penyelesaian. Evaluate (menilai) merupakan kegiatan berpikir yang dimana menilai proses dalam mengerjakan suatu permasalahan, seperti yang dikemukakan oleh Anderson dan Krathwohl (2001) evaluate didefinisikan sebagai membuat penilaian berdasarkan kriteria dan standar yang ditentukan. Kriteria yang paling sering digunakan dalam ranah kognitif evaluate adalah kualitas, efektivitas, efisiensi, dan konsistensi. Lebih lanjut Anderson dan Krathwohl menjelaskan bahwa tidak semua penilaian bersifat evaluatif. Misalnya, siswa membuat penilaian tentang apakah metode yang digunakan dalam menyelesaikan soal sudah yang paling terbaik. Siswa membuat penilaian tentang kesesuaian prosedur tertentu untuk masalah tertentu, yaitu membuat penilaian tentang dua metode yang akan digunakan. 
Sebagian besar proses kognitif, pada kenyataannya, memerlukan beberapa bentuk penilaian. Hal yang paling jelas membedakan mengevaluasi sebagaimana didefinisikan di sini dari penilaian lain yangdibuat oleh siswa adalah penggunaan standar kinerja dengan kriteria yang jelas, contoh: apakah metode yang digunakan efisien dan merupakan cara terbaik,atau metode yang digunakan lebih cepat menyelesaikan masalah daripada metode lain,pertanyaan semacam itu merupakan kegiatan kognitif terlibat dalam evaluate.

Anderson dan Krathwohl (2001) menjelaskan ranah kognitif create (mencipta) merupakan kegiatan mengombinasikan berbagai elemen ke dalam bentuk yang baru. Lebih lanjut Anderson dan Krathwohl menjelaskan proses yang terlibat dalam create umumnya dikoordinasikan dengan pengalaman belajar siswa sebelumnya dan create membutuhkan pemikiran kreatif dari pihak siswa. Jadi ranah kognitif create pada soal HOTS merupakan proses berpikir untuk menyelesaikan masalah dengan menghubungkan pengetahuan yang lain untuk menciptakan hal baru sebagai jawaban memecahkan masalah yang diberikan. Jika bicara mengenai soal HOTS matematika, maka soal tersebut merupakan masalah matematika yang terdapat pada ranah kognitif menganalisis (analyze), menilai (evaluate), dan mencipta (create). Peneliti menggunakan soal HOTS dengan ranah kognitif analyze.

Karakteristik kemampuan berpikir tingkat tinggi adalah kemampuan berpikir kritis dan kemampuan pemecahan masalah. Seperti yang dikemukakan oleh Tanujaya (2016) Instrumen yang digunakan untuk mengukur HOTS pada siswa sekolah menengah untuk pengajaran matematika terdapat sembilan item, salah satunya merupakan kemampuan pemecahan masalah. Hal tersebut sejalan dengan pernyataan NCTM (2000) terdapat lima keterampilan proses yang dimiliki peserta didik melalui mata pelajaran matematika yang tercakup dalam standar proses, yaitu pemecahan masalah, penalaran dan pembuktian, komunikasi, koneksi, dan representasi. Budiman dan Jailani (2014) menyatakan bahwa keterampilan-keterampilan tersebut termasuk pada berpikir matematika tingkat tinggi. Pernyataan tersebut dapat ditarik kesimpulan bahwa kemampuan berpikir tingkat tingkat tinggi mencakup keterampilan bernalar. Penalaran kuantatif sendiri merupakan suatu proses yang tujuan akhirnya merupakan menyelesaikan permasalahan, seperti yang dikemukakan oleh Dwyer (2003) penalaran kuantitatif, baik secara umum maupun untuk tujuan penilaian, difokuskan pada pemecahan masalah. Jika seorang siswa mempunyai kemampuan penalaran yang baik maka kemungkinan untuk menyelesaikan/memecahkan suatu masalah dalam matematika menjadi mudah (Sroyer, 2013). Dari pernyataan-pernyataan tersebut, dapat disimpulkan bahwa hubungan penalaran kuantitatif dengan soal HOTS adalah kemampuan menganalisis informasi kuantitatif pada soal HOTS untuk menemukan solusi dalam menyelesaikan permasalahan. 


\section{METODE}

Penelitian ini adalah penelitian kualitatif yang bertujuan untuk mendeskripsikan penalaran kuantitatif siswa SMA dalam menyelesaikan soal HOTS. Teknik pengambilan sampel yang peneliti gunakan teknik purposive sampling yaitu pengambilan subjek dengan pertimbangan tertentu. Penelitian ini dilaksanakan di kelas X MIPA 2 SMA Muhammadiyah 3 Tulangan pada semester genap tahun ajaran 2019/2020. Jumlah siswa X MIPA 2 sebanyak 33 siswa, kemudian siswa dikelompokkan berdasarkan kemampuan matematika siswa berdasarkan nilai matematika dan hasil diskusi dengan guru. Diperoleh 4 siswa berkemampuan matematika tinggi, 22 siswa berkemampuan matematika sedang, dan 7 siswa berkemampuan matematika rendah. Kemudian peneliti diskusi lebih lanjut dengan guru mengenai kemampuan komunikasi siswa, sehingga didapatkan satu siswa berkemampuan matematika tinggi, satu siswa berkemampuan matematika sedang, dan satu siswa berkemampuan matematika rendah, dengan memiliki kemampuan komunikasi yang baik. Daftar nama subjek penelitian disajikan sebagai berikut:

\section{Tabel 1. Daftar Kode Subjek Penelitian}

\begin{tabular}{ccc}
\hline No. & Nama & Tingkat Kemampuan Matematika \\
\hline 1. & VNV & Tinggi \\
\hline 2. & AIS & Sedang \\
\hline 3. & VDR & Rendah \\
\hline
\end{tabular}

Instrumen dalam penelitian ini yaitu soal tes dan wawancara. Penelitian ini menggunakan triangulasi waktu sehingga ada tes soal HOTS waktu pertama (TSH) 1 dengan tes wawancara 1 dan tes soal HOTS waktu kedua (TSH) 2 dengan tes wawancara 2. Data yang diperoleh kemudian dianalisis dengan menggunakan triangulasi waktu dengan membandingkan data waktu pertama dengan waktu kedua.

\section{HASIL DAN PEMBAHASAN}

Data yang didapat akan dianalisis berdasarkan indikator penalaran kuantitatif. Peneliti menggunakan indikator penalaran kuantitatif yang diadaptasi dari Fuadiah (2015).

Tabel 2. Indikator Penalaran Kuantitatif (Fuadiah, 2015)

\begin{tabular}{|c|c|c|}
\hline No. & Deskriptor & Indikator \\
\hline \multirow[t]{3}{*}{1.} & \multirow[t]{3}{*}{$\begin{array}{l}\text { Membaca dan memahami } \\
\text { informasi dalam berbagai } \\
\text { bentuk. }\end{array}$} & $\begin{array}{l}\text { a. Membaca informasi dalam berbagai } \\
\text { bentuk (kata-kata, rumus, tabel, atau } \\
\text { grafik). }\end{array}$ \\
\hline & & $\begin{array}{l}\text { b. Memahami dan menganalisis informasi } \\
\text { eksplisit dan implisit dalam soal. }\end{array}$ \\
\hline & & c. Menentukan batasan masalah \\
\hline \multirow[t]{2}{*}{2.} & \multirow[t]{2}{*}{$\begin{array}{l}\text { Menginterpretasi informasi } \\
\text { kuantitatif dan menarik } \\
\text { kesimpulan hasil interpretasi } \\
\text { tersebut. }\end{array}$} & $\begin{array}{l}\text { a. Menginterpretasi kuantitas tertentu yang } \\
\text { berhubungan atau berubah atau } \\
\text { bertransformasi menjadi kuantitas lain } \\
\text { baik yang diberikan secara eksplisit } \\
\text { maupun implisit. }\end{array}$ \\
\hline & & b. Menarik kesimpulan hasil interpretasi. \\
\hline
\end{tabular}




\begin{tabular}{|c|c|c|}
\hline No. & Deskriptor & Indikator \\
\hline \multirow[t]{4}{*}{3.} & \multirow{4}{*}{$\begin{array}{l}\text { Memecahkan masalah } \\
\text { menggunakan metode } \\
\text { aritmatika, aljabar, geometri } \\
\text { atau statistik. }\end{array}$} & $\begin{array}{l}\text { a. Mengetahui informasi yang dibutuhkan } \\
\text { untuk menyelesaikan soal. }\end{array}$ \\
\hline & & $\begin{array}{l}\text { b. Menentukan dan menggunakan metode } \\
\text { aritmatika, aljabar, geometri atau statistik } \\
\text { untuk menyelesaikan soal. }\end{array}$ \\
\hline & & $\begin{array}{l}\text { c. Menggunakan berbagai teknik yang } \\
\text { dapat digunakan untuk memecahkan } \\
\text { masalah (misalnya, menggambar } \\
\text { gambar, menggunakan rumus, } \\
\text { menyelesaikan persamaan). }\end{array}$ \\
\hline & & $\begin{array}{l}\text { d. Menerapkan teknik dengan benar untuk } \\
\text { menyelesaikan masalah. }\end{array}$ \\
\hline \multirow[t]{5}{*}{4.} & \multirow[t]{5}{*}{$\begin{array}{l}\text { Memperkirakan dan memeriksa } \\
\text { kemasuk-akalan jawaban. }\end{array}$} & $\begin{array}{l}\text { a. Memilih dan menggunakan strategi } \\
\text { komputasi yang tepat dan efisien untuk } \\
\text { menyelesaikan soal. }\end{array}$ \\
\hline & & $\begin{array}{l}\text { b. Menentukan tingkat akurasi perhitungan } \\
\text { yang diperlukan atau kesesuaian } \\
\text { menggunakan estimasi untuk memeriksa } \\
\text { jawaban. }\end{array}$ \\
\hline & & $\begin{array}{l}\text { c. Mengetahui ketika kesalahan telah terjadi } \\
\text { dalam proses penalaran. }\end{array}$ \\
\hline & & $\begin{array}{l}\text { d. Memeriksa jawaban atau hasil dan } \\
\text { mengakui ketika jawaban atau hasil tidak } \\
\text { masuk akal. }\end{array}$ \\
\hline & & $\begin{array}{l}\text { e. Mengetahui implikasi dari jawaban atau } \\
\text { hasil. }\end{array}$ \\
\hline \multirow[t]{3}{*}{5.} & \multirow[t]{3}{*}{$\begin{array}{l}\text { Mengkomunikasikan informasi } \\
\text { kuantitatif. }\end{array}$} & $\begin{array}{l}\text { a. Mengkomunikasikan seluruh informasi } \\
\text { kuantitatif dalam proses menyelesaikan } \\
\text { soal. }\end{array}$ \\
\hline & & $\begin{array}{l}\text { b. } \begin{array}{l}\text { Mengkomunikasikan hasil, } \\
\text { secara tertulis (atau mode laikan } \\
\text { penjelasan jelas dan } \\
\text { menyelesaikan soal. }\end{array} \\
\text { dari proses } \\
\end{array}$ \\
\hline & & $\begin{array}{l}\text { c. Menerjemahkan hasil yang telah didapat } \\
\text { secara matematis ke bahasa masalah. }\end{array}$ \\
\hline 6. & $\begin{array}{l}\text { Mengenali keterbatasan metode } \\
\text { matematis yang digunakan. }\end{array}$ & $\begin{array}{l}\text { Menyebutkan keterbatasan metode } \\
\text { matematis yang digunakan dalam } \\
\text { memecahkan masalah secara lisan maupun } \\
\text { tulisan. }\end{array}$ \\
\hline
\end{tabular}

Hasil analisis data penalaran kuantitatif siswa dalam menyelesaikan soal HOTS dari ketiga subjek berdasarkan indikator penalaran kuantitatif, terlihat bahwa terdapat perbedaan dalam pencapaian indikator penalaran kuantitatif. Berikut tabel hasil analisis yang sudah dilakukan.

\begin{tabular}{|c|c|c|c|c|c|c|}
\hline \multirow{3}{*}{ Indikator } & \multicolumn{2}{|c|}{ Subjek VNV } & \multicolumn{2}{|c|}{ Subjek AIS } & \multicolumn{2}{|c|}{ Subjek VDR } \\
\hline & TSH & TSH & TSH & TSH & TSH & TSH \\
\hline & 1 & 2 & 1 & 2 & 1 & 2 \\
\hline $\begin{array}{l}\text { 1(a) Membaca informasi dalam berbagai } \\
\text { bentuk (kata-kata, rumus, tabel, atau } \\
\text { grafik). }\end{array}$ & $\sqrt{ }$ & $\sqrt{ }$ & $\sqrt{ }$ & $\sqrt{ }$ & $x$ & $x$ \\
\hline $\begin{array}{l}\text { 1(b) Memahami dan menganalisis informasi } \\
\text { eksplisit dan implisit dalam soal. }\end{array}$ & $x$ & $\times$ & $x$ & $x$ & $x$ & $x$ \\
\hline 1(c) Menentukan batasan masalah & $x$ & $\sqrt{ }$ & $\sqrt{ }$ & $\sqrt{ }$ & $x$ & $x$ \\
\hline $\begin{array}{l}\text { 2(a) Menginterpretasi kuantitas tertentu yang } \\
\text { berhubungan atau berubah atau } \\
\text { bertransformasi menjadi kuantitas lain }\end{array}$ & $x$ & $\sqrt{ }$ & $\times$ & $\sqrt{ }$ & $x$ & $x$ \\
\hline
\end{tabular}




\begin{tabular}{|c|c|c|c|c|c|c|}
\hline \multirow[b]{2}{*}{ Indikator } & \multicolumn{2}{|c|}{ Subjek VNV } & \multicolumn{2}{|c|}{ Subjek AIS } & \multicolumn{2}{|c|}{ Subjek VDR } \\
\hline & $\begin{array}{c}\text { TSH } \\
1\end{array}$ & $\begin{array}{c}\text { TSH } \\
2\end{array}$ & $\begin{array}{c}\text { TSH } \\
1\end{array}$ & $\begin{array}{c}\text { TSH } \\
2\end{array}$ & $\begin{array}{c}\text { TSH } \\
1\end{array}$ & $\begin{array}{c}\text { TSH } \\
2\end{array}$ \\
\hline $\begin{array}{l}\text { baik yang diberikan secara eksplisit } \\
\text { maupun implisit. }\end{array}$ & & & & & & \\
\hline 2(b) Menarik kesimpulan hasil interpretasi. & $x$ & $\sqrt{ }$ & $x$ & $x$ & $x$ & $x$ \\
\hline $\begin{array}{l}\text { 3(a) Mengetahui informasi yang dibutuhkan } \\
\text { untuk menyelesaikan soal. }\end{array}$ & $\sqrt{ }$ & $\sqrt{ }$ & $\sqrt{ }$ & $\sqrt{ }$ & $\sqrt{ }$ & $\sqrt{ }$ \\
\hline $\begin{array}{l}\text { 3(b) Menentukan dan menggunakan metode } \\
\text { aritmatika, aljabar, geometri atau } \\
\text { statistik untuk menyelesaikan soal. }\end{array}$ & $\sqrt{ }$ & $\sqrt{ }$ & $\sqrt{ }$ & $\sqrt{ }$ & $\sqrt{ }$ & $\sqrt{ }$ \\
\hline $\begin{array}{l}\text { 3(c) Menggunakan berbagai teknik yang } \\
\text { dapat digunakan untuk memecahkan } \\
\text { masalah (misalnya, menggambar } \\
\text { gambar, menggunakan rumus, } \\
\text { menyelesaikan persamaan). }\end{array}$ & $\sqrt{ }$ & $\sqrt{ }$ & $\sqrt{ }$ & $x$ & $\sqrt{ }$ & $x$ \\
\hline $\begin{array}{l}\text { 3(d) Menerapkan teknik dengan benar untuk } \\
\text { menyelesaikan masalah. }\end{array}$ & $x$ & $\times$ & $\times$ & $x$ & $x$ & $x$ \\
\hline $\begin{array}{l}\text { 4(a) Memilih dan menggunakan strategi } \\
\text { komputasi yang tepat dan efisien untuk } \\
\text { menyelesaikan soal. }\end{array}$ & $x$ & $x$ & $x$ & $\sqrt{ }$ & $\times$ & $x$ \\
\hline $\begin{array}{l}\text { 4(b) Menentukan tingkat akurasi } \\
\text { perhitungan yang diperlukan atau } \\
\text { kesesuaian menggunakan estimasi untuk } \\
\text { memeriksa jawaban. }\end{array}$ & $\sqrt{ }$ & $\times$ & $x$ & $x$ & $x$ & $x$ \\
\hline $\begin{array}{l}\text { 4(c) Mengetahui ketika kesalahan telah } \\
\text { terjadi dalam proses penalaran. }\end{array}$ & $x$ & $\sqrt{ }$ & $\times$ & $x$ & $x$ & $x$ \\
\hline $\begin{array}{l}\text { 4(d) Memeriksa jawaban atau hasil dan } \\
\text { mengakui ketika jawaban atau hasil } \\
\text { tidak masuk akal. }\end{array}$ & $x$ & $x$ & $x$ & $x$ & $x$ & $x$ \\
\hline $\begin{array}{l}\text { 4(e) Mengetahui implikasi dari jawaban atau } \\
\text { hasil. }\end{array}$ & $x$ & $x$ & $x$ & $\sqrt{ }$ & $\times$ & $x$ \\
\hline $\begin{array}{l}\text { 5(a) Mengkomunikasikan seluruh informasi } \\
\text { kuantitatif dalam proses menyelesaikan } \\
\text { soal. }\end{array}$ & $x$ & $x$ & $\times$ & $x$ & $\times$ & $x$ \\
\hline $\begin{array}{l}\text { 5(b) Mengkomunikasikan hasil, disajikan } \\
\text { secara tertulis (atau mode lain) dan } \\
\text { penjelasan jelas dari proses } \\
\text { menyelesaikan soal. }\end{array}$ & $x$ & $x$ & $x$ & $x$ & $x$ & $x$ \\
\hline $\begin{array}{l}\text { 5(c) Menerjemahkan hasil yang telah } \\
\text { didapat secara matematis ke bahasa } \\
\text { masalah. }\end{array}$ & $x$ & $x$ & $x$ & $\times$ & $x$ & $x$ \\
\hline $\begin{array}{l}6 \text { Menyebutkan keterbatasan metode } \\
\text { matematis yang digunakan dalam } \\
\text { memecahkan masalah secara lisan maupun } \\
\text { tulisan. }\end{array}$ & $\sqrt{ }$ & $x$ & $\sqrt{ }$ & $x$ & $x$ & $\times$ \\
\hline $\begin{array}{l}\text { Keterangan : } \\
\sqrt{ }=\text { Memenuhi } \\
\times=\text { Tidak Memenuhi }\end{array}$ & & & & & & \\
\hline
\end{tabular}

Berdasarkan analisis yang telah dilakukan pada waktu pertama dan waktu kedua, subjek VNV dan subjek AIS dapat menyebutkan informasi pada soal dengan baik dan tepat, sehingga subjek VNV dan subjek AIS memenuhi indikator membaca informasi dalam berbagai bentuk, sedangkan subjek VDR tidak dapat menyebutkan informasi pada soal dengan baik pada waktu pertama dan waktu kedua, sehingga subjek VDR tidak memenuhi indikator membaca informasi dalam berbagai bentuk.Berdasarkan analisis yang telah dilakukan pada waktu pertama dan waktu kedua, subjek VNV 
dan subjek AIS hanya dapat menyebutkan informasi eksplisit, sedangkan dalam menganalisis informasi implisit kurang baik, sehingga subjek VNV dan subjek AIS tidak memenuhi indikator memahami dan menganalisis informasi eksplisit dan implisit dalam soal. Subjek VDR tidak dapat menganalisis informasi implisit maupun eksplisit pada waktu pertama dan waktu kedua, sehingga subjek VDR tidak memenuhi indikator memahami dan menganalisis informasi eksplisit dan implisit dalam soal.

Subjek VNV pada waktu pertama tidak dapat menyebutkan keterbatasan masalah dengan baik, sedangkan pada waktu kedua dapat menyebutkan keterbatasan masalah dengan baik, karena subjek hanya dapat menyebutkan keterbatasan masalah dengan benar pada waktu kedua maka subjek VNV tidak memenuhi indikator menentukan batasan masalah. Subjek VDR tidak dapat menyebutkan keterbatasan masalah dengan baik pada waktu pertama maupun waktu kedua, sehingga subjek VDR tidak memenuhi indikator menentukan batasan masalah. Subjek AIS dapat menyebutkan keterbatasan masalah dengan baik di waktu pertama maupun waktu kedua, sehingga subjek AIS memenuhi indikator menentukan batasan masalah.

Subjek VDR tidak dapat menginterpretasi data dengan baik pada waktu pertama dan waktu kedua, sehingga subjek VDR tidak memenuhi indikator menginterpretasi kuantitas tertentu yang berhubungan atau berubah atau bertransformasi menjadi kuantitas lain baik yang diberikan secara eksplisit maupun implisit, sedangkan subjek VNV dan subjek AIS tidak dapat menginterpretasi data dengan baik pada waktu kedua, karena subjek VNV dan subjek AIS hanya dapat menginterpretasi data dengan baik pada waktu pertama maka keduanya tidak memenuhi indikator menginterpretasi kuantitas tertentu yang berhubungan atau berubah atau bertransformasi menjadi kuantitas lain baik yang diberikan secara eksplisit maupun implisit.

Dalam menyimpulkan makna dari kedua data yang diberikan pada waktu pertama, subjek VNV kurang tepat menyimpulkannya, sedangkan pada waktu kedua subjek tepat dalam menyimpulkan makna dari kedua data yang diberikan, karena subjek hanya dapat menyimpulkan makna dari kedua data yang diberikan pada waktu kedua, maka subjek VNV tidak memenuhi indikator menarik kesimpulan hasil interpretasi. Subjek AIS dan subjek VDR kurang tepat dalam menyimpulkan makna dari kedua data yang diberikan pada waktu pertama dan waktu kedua, sehingga subjek AIS dan subjek VDR tidak memenuhi indikator menarik kesimpulan hasil interpretasi.

Ketiga subjek menjawab soal dengan memanfaatkan informasi pada soal kemudian dianalisis informasi tersebut, sehingga etiga subjek mengetahui informasi yang dibutuhkan untuk menyelesaikan soal pada waktu pertama dan waktu kedua, maka ketiga subjek memenuhi indikator mengetahui informasi yang dibutuhkan untuk menyelesaikan soal. Ketiga subjek pada waktu pertama dan waktu kedua menyelesaikan soal dengan metode aritmatika, sehingga ketiga subjek memenuhi indikator 
menentukan dan menggunakan metode aritmatika, aljabar, geometri atau statistik untuk menyelesaikan soal.

Subjek VNV pada waktu pertama dan waktu kedua menggunakan teknik dalam menyelesaikan soal sehingga subjek VNV memenuhi indikator menggunakan berbagai teknik yang dapat digunakan untuk memecahkan masalah. Subjek AIS dan VDR menggunakan teknik pada waktu pertama, sedangkan pada waktu kedua tidak menggunakan teknik, karena hanya menggunakan teknik pada waktu pertama, maka subjek AIS dan subjek VDR tidak memenuhi indikator menggunakan berbagai teknik yang dapat digunakan untuk memecahkan masalah.

Subjek VNV tidak menggunakan teknik dengan benar pada waktu pertama maupun waktu kedua, sehingga subjek VNV tidak memenuhi indikator menerapkan teknik dengan benar untuk menyelesaikan masalah. Pada waktu pertama subjek AIS dan subjek VDR tidak menggunakan teknik dengan benar, sedangkan waktu kedua tidak menggunakan teknik, jadi subjek AIS dan subjek VDR tidak memenuhi indikator menerapkan teknik dengan benar untuk menyelesaikan masalah.

Subjek AIS pada waktu pertama kurang dapat menggunakan strategi yang digunakan dengan baik, sedangkan pada waktu kedua dapat menggunakan strategi yang digunakan dengan baik, karena subjek hanya dapat menggunakan strategi yang digunakan dengan baik pada waktu kedua, maka subjek AIS tidak memenuhi indikator memilih dan menggunakan strategi komputasi yang tepat dan efisien untuk menyelesaikan soal. Subjek VNV dan subjek VDR kurang dapat menggunakan strategi yang digunakan dengan baik pada waktu pertama dan waktu kedua, sehingga subjek VNV dan subjek VDR tidak memenuhi indikator memilih dan menggunakan strategi komputasi yang tepat dan efisien untuk menyelesaikan soal.

Subjek VNV hanya dapat menentukan tingkat akurasi perhitungan pada waktu pertama, sedangkan subjek AIS dan subjek VDR tidak dapat menentukan tingkat akurasi perhitungan pada waktu pertama dan waktu kedua, maka ketiga subjek tidak memenuhi indikator menentukan tingkat akurasi perhitungan yang diperlukan atau kesesuaian menggunakan estimasi untuk memeriksa jawaban.

Subjek AIS dan subjek VDR tidak menyadari kesalahan telah terjadi pada saat menyelesaikan soal pada waktu pertama dan waktu kedua, sedangkan subjek VNV tidak menyadari kesalahan telah terjadi pada saat menyelesaikan soal pada waktu pertama, maka ketiga subjek tidak memenuhi indikator mengetahui ketika kesalahan telah terjadi dalam proses penalaran.

Subjek VNV dan subjek VDR tidak menyadari ketidak masuk akalan jawabannya pada waktu pertama dan waktu kedua. Subjek AIS tidak menyadari ketidak masuk akalan jawabannya pada waktu pertama, sedangkan pada waktu kedua subjek AIS tidak memeriksa hasil pekerjaannya sehingga tidak 
mengetahui jawaban atau hasil tidak masuk akal, jadi ketiga subjek tidak memenuhi indikator memeriksa jawaban atau hasil dan mengakui ketika jawaban atau hasil tidak masuk akal.

Subjek VNV dan subjek VDR pada waktu pertama dan waktu kedua tidak mengetahui hubungan cara yang digunakan dengan jawaban hasil akhir, sedangkan pada waktu pertama jawaban subjek AIS tidak ada hubungan dengan kedua data yang diberikan, sehingga ketiga subjek tidak memenuhi indikator mengetahui implikasi dari jawaban atau hasil.

Ketiga subjek Pada waktu pertama maupun waktu kedua, tidak dapat memahami dan menganalisis informasi eksplisit dan implisit dalam soal, menentukan batasan masalah, menginterpretasi kuantitas tertentu yang berhubungan atau berubah atau bertransformasi menjadi kuantitas lain baik yang diberikan secara eksplisit maupun implisit, dan menyebutkan keterbatasan metode matematis yang digunakan dalam memecahkan masalah secara lisan maupun tulisan, maka ketiga subjek tidak memenuhi indikator mengkomunikasikan seluruh informasi kuantitatif dalam proses menyelesaikan soal.

Subjek AIS pada waktu pertama dan waktu kedua tidak dapat memahami dan menganalisis informasi eksplisit dan implisit dalam soal, menginterpretasi kuantitas tertentu yang berhubungan atau berubah atau bertransformasi menjadi kuantitas lain baik yang diberikan secara eksplisit maupun implisit, dan menyebutkan keterbatasan metode matematis yang digunakan dalam memecahkan masalah secara lisan maupun tulisan, maka subjek AIS tidak memenuhi indikator mengkomunikasikan seluruh informasi kuantitatif dalam proses menyelesaikan soal.

Subjek VDR pada waktu pertama dan waktu kedua, tidak dapat membaca informasi dalam berbagai bentuk, memahami dan menganalisis informasi eksplisit dan implisit dalam soal, menentukan batasan masalah, menginterpretasi kuantitas tertentu yang berhubungan atau berubah atau bertransformasi menjadi kuantitas lain baik yang diberikan secara eksplisit maupun implisit, dan menyebutkan keterbatasan metode matematis yang digunakan dalam memecahkan masalah secara lisan maupun tulisan, maka subjek VDR tidak memenuhi indikator mengkomunikasikan seluruh informasi kuantitatif dalam proses menyelesaikan soal.

Ketiga subjek pada waktu pertama dan waktu kedua tidak dapat menarik kesimpulan hasil interpretasi, memilih dan menggunakan strategi komputasi yang tepat dan efisien untuk menyelesaikan soal, menentukan tingkat akurasi perhitungan yang diperlukan atau kesesuaian menggunakan estimasi untuk memeriksa jawaban, mengetahui ketika kesalahan telah terjadi dalam proses penalaran, memeriksa jawaban atau hasil dan mengakui ketika jawaban atau hasil tidak masuk akal, mengetahui implikasi dari jawaban atau hasil, maka ketiga subjek tidak memenuhi indikator mengkomunikasikan hasil, disajikan secara tertulis (atau mode lain) dan penjelasan jelas dari proses menyelesaikan soal. 
Subjek VNV pada waktu pertama dan waktu kedua, tidak dapat menerapkan teknik dengan benar untuk menyelesaikan masalah, maka subjek VNV tidak memenuhi indikator menerjemahkan hasil yang telah didapat secara matematis ke bahasa masalah. Subjek AIS dan subjek VDR pada waktu pertama dan waktu kedua, tidak menggunakan berbagai teknik yang dapat digunakan untuk memecahkan masalah dan tidak menerapkan teknik dengan benar untuk menyelesaikan masalah, maka subjek AIS dan subjek VDR tidak memenuhi indikator menerjemahkan hasil yang telah didapat secara matematis ke bahasa masalah.

Subjek VNV dan subjek AIS pada waktu kedua tidak dapat menyebutkan keterbatasan metode yang digunakan, sehingga tidak memenuhi indikator menyebutkan keterbatasan metode matematis yang digunakan dalam memecahkan masalah secara lisan maupun tulisan. Subjek VDR pada waktu pertama dan waktu kedua tidak dapat menyebutkan keterbatasan metode yang digunakan, sehingga tidak memenuhi indikator menyebutkan keterbatasan metode matematis yang digunakan dalam memecahkan masalah secara lisan maupun tulisan.

Menurut hasil penelitian, penalaran kuantitatif siswa dengan kemampuan matematika tinggi hanya dapat membaca informasi dalam berbagai bentuk, mengetahui informasi yang dibutuhkan untuk menyelesaikan soal, menentukan dan menggunakan metode aritmatika, aljabar, geometri atau statistik untuk menyelesaikan soal, dan menggunakan berbagai teknik yang dapat digunakan untuk memecahkan masalah. Hal ini bertentangan dengan penelitian sebelumnya oleh Dewi (2018) yang menyatakan bahwa siswa dengan berkemampuan matematika tinggi dapat memenuhi semua indikator penalaran kuantitatif, sedangkan berdasarkan Zalinin, dkk (2018) penalaran kuantitatif siswa dengan kemampuan matematika tinggi dalam kategori baik, namun tidak semua indikator penalaran kuantitatif terpenuhi.Penalaran kuantitatif siswa dengan kemampuan matematika sedang hanya dapat membaca informasi dalam berbagai bentuk, menentukan batasan masalah, mengetahui informasi yang dibutuhkan untuk menyelesaikan soal, dan menentukan dan menggunakan metode aritmatika, aljabar, geometri atau statistik untuk menyelesaikan soal. Hal ini bertentangan dengan Dewi (2018) yang menyatakan siswa yang memiliki kemampuan matematika sedang dapat mencapai semua indikator pada penalaran kuantitatif, tetapi berdasarkan Zalinin, dkk (2018) penalaran kuantitatif siswa dengan kemampuan matematika sedang dalam kategori sangat kurang.

Ketidaksesuaian ini dikarenakan soal yang diberikan pada penelitian-penelitian sebelumnya bukan soal tipe berpikir tingkat tinggi sedangkan soal yang digunakan pada penelitian ini merupakan soal tipe berpikir tingkat tinggi. Pada penelitian ini siswa kurang dapat menyelesaikan soal HOTS dengan tepat, karena dilihat dari analisis yang telah dilakukan, siswa mengetahui maksud dari soal tetapi kurang tepat dalam menentukan metode yang tepat untuk menyelesaikan soal, hal ini sejalan dengan Permana (2019) yang menyatakan bahwa dalam menyelesaikan soal HOTS siswa mengalami 
kesalahan konsep, dimana siswa tahu apa yang harus mereka cari, tetapi tidak dapat menentukan rumus yang harus digunakan untuk menyelesaikan soal. Jadi dalam menyelesaikan soal HOTS, siswa tidak dapat bernalar kuantitatif dengan baik.

Penalaran kuantitatif siswa dengan kemampuan matematika rendah hanya dapat mengetahui informasi yang dibutuhkan untuk menyelesaikan soal, menentukan dan menggunakan metode aritmatika, aljabar, geometri atau statistik untuk menyelesaikan soal. Hal ini bertentangan dengan Dewi (2018) yang menyatakan siswa dengan kemampuan matematika rendah tidak dapat mencapai semua indikator pada penalaran kuantitatif, tetapi hal ini sejalan dengan Zalinin, dkk (2018) yang menyatakan kemampuan penalaran kuantitatif siswa pada tingkat kemampuan matematika rendah berada pada kategori sangat kurang tetapi terdapat indikator yang terpenuhi. Hal ini juga sejalan dengan penelitian Widiah (2019) yang menyatakan tidak semua indikator terpenuhi oleh siswa berkemampuan matematika rendah.

\section{SIMPULAN}

Berdasarkan hasil analisis data yang sudah dilakukan, dapat disimpulkan bahwa dalam menyelesaikan soal HOTS, penalaran kuantitatif siswa berkemampuan matematika tinggi hanya dapat mengetahui informasi yang dibutuhkan untuk menyelesaikan soal; menentukan dan menggunakan metode aritmatika, aljabar, geometri atau statistik untuk menyelesaikan soal; dan menggunakan berbagai teknik yang dapat digunakan untuk memecahkan masalah. Kemudian dalam menyelesaikan soal HOTS, penalaran kuantitatif siswa berkemampuan matematika sedang hanya dapat menentukan batasan masalah; mengetahui informasi yang dibutuhkan untuk menyelesaikan soal; menentukan dan menggunakan metode aritmatika, aljabar, geometri atau statistik untuk menyelesaikan soal. Sedangkan dalam menyelesaikan soal HOTS, penalaran kuantitatif siswa berkemampuan matematika rendah hanya dapat mengetahui informasi yang dibutuhkan untuk menyelesaikan soal; menentukan dan menggunakan metode aritmatika, aljabar, geometri atau statistik untuk menyelesaikan soal.

Penelitian ini memiliki kelemahan, yaitu wawancara pada penelitian ini keterbatasan waktu, seharusnya waktu untuk melakukan wawancara lebih lama agar dapat lebih memperdalam kemampuan penalaran kuantitatif siswa, karena sebagian besar untuk pemenuhan indikator penalaran kuantitatif pada penelitian ini diperoleh dengan wawancara.

\section{REFERENSI}

Anderson, L. W., \& Krathwohl, D. R. (2001). A Taxonomy for Learning, Teaching, and Assessing (A Revision of Bloom's Taxonomyof Educational Objectives). New York: Longman. 
Budiman, A., \& Jailani. (2014). Pengembangan Instrumen Asesmen Higher Order Thinking Skill (HOTS) Pada Mata Pelajaran Matematika SMP Kelas Viii Semester 1. Jurnal Riset Pendidikan Matematika, 139-151.

Carroll, J. B. (1993). Human Cognitive Abilities: A Survey of Factor-Analytic Studies. Cambridge: Cambridge University Press.

Dafik. (2014, Juli 01 ). dafik-fkip-unej.org. Retrieved Maret 03, 2018, from dafik-fkip-unej.org: https://dafik-fkip-unej.org/berita-199-keterampilan-berpikir-tingkat-tinggi-hots.html

Dewi, N. F. (2018). Profil Penalaran Kuantitatif Dalam Memecahkan Masalah Matematika Ditinjau Dari Kecerdasan Numerik. Universitas Islam Negeri Sunan Ampel Surabaya.

Dwyer, C. A., Gallagher, A., Levin, J., Morley, M. E. (2003). What is Quantitative Defining the Construct for Assessment. Princeton: Educational Testing Service.

Elrod, S. (2014). AAC \& U. Retrieved March 1, 2018, from AAC \& U: https://www.aacu.org/peerreview/2014/summer/elrod.

Fuadiah, D. (2015) Tesis: "Profil Penalaran Kuantitatif Siswa SMP Ditinjau dari Gender"(tesis tidak dipublikasikan). (Surabaya: Universitas Negeri Surabaya, 2015).

Jailani, Sugiman, Retnawati, H., Bukhori, Apino, E., Djidu, H., et al. (2017). Desain Pembelajaran Matematika untuk Melatihkan Higher Order Thinking Skills. Yogyakarta: UNY Press.

Kilpatrick, J., Swafford, J., \& Findell, B. (Eds.). (2001). Adding it up: Helping children learn mathematics. Washington, DC: National Academy Press.

NCTM. (2000). Principles and standard for school mathematics. Reston, VA: The National Council of Teacher Mathematics, Inc.

Partnership for $21^{\text {st }}$ Century Skills. (2002). Learning for the 21st century: A report and mile guide for $21^{\text {st }}$ century skills. Tucson, AZ: Author.

Permana, N. N. (2019). Analisis Kesalahan Siswa dalam Menyelesaikan Soal Higher Order Thinking Skills (HOTS) Matematika. Prosiding DPNPM Unindra 2019 (pp. 19-24). Jakarta: Universitas Indraprasta PGRI.

Sroyer, A. (2013, November 09). Penalaran Kuantitatif (Quantitative Reasoning) Dalam Pemecahan Masalah Matematika. Seminar Nasional Matematika dan Pendidikan Matematika dengan tema "Penguatan Peran Matematika dan Pendidikan Matematika untuk Indonesia yang Lebih Baik", hal. 39-44.

Tanujaya, B. (2016). Development of an Instrument to Measure Higher Order Thinking Skills in Senior High School Mathematics Instruction. Journal of Education and Practice , 144-148.

Widiah, I. T. (2019). Profil Penalaran Kuantitatif Siswa SMP Dalam Memecahkan Masalah. STKIP PGRI Sidoarjo.

Yuliardi, R., \& Lutfi, A. F. (2018). Pengembangan Media Pembelajaran Berbasis Adobe Flash Untuk Meningkatkan Kemampuan Penalaran Matematis Siswa. EduMa, 81-87.

Zalinin, Sugiatno, \& Suratman, D. (2019). Kemampuan Penalaran Kuantitatif Siswa dalam Materi Aljabar Di Sekolah Menengah Atas. Jurnal Pendidikan dan Pembelajaran Khatulistiwa. 